\title{
Whither the Funnel of Causality?
}

\author{
MATt WILDER University of Toronto
}

\section{Introduction}

Richard Simeon's objective in "Studying Public Policy" was to establish both why political scientists ought to study public policy and how they should go about it. In approaching his second task, Simeon took pains to operationalize the variables necessary for the study of public policy to proceed as systematically as possible. From this concern arose a method for dependent variable disaggregation focused on scope, means, and distribution, and a method for organizing and understanding the dynamic interplay of causal variables in the policy process. This article focuses on the latter. Specifically, it inquires as to the staying power of a conceptual device championed by Simeon called the "funnel of causality."

The funnel of causality was important to Simeon's project because it sketched the considerations required for theory building. Relatedly, the funnel of causality sought to advance a methodology appropriate to the study of public policy. Owing to the fact that its development preceded the fragmentation of political science into its many subfields, the funnel of causality reflects a broader and more integrated approach to social scientific inquiry than is currently the norm. In other words, the funnel of causality is sensitive to a range of inputs from numerous levels of abstraction. It was consequently celebrated by its proponents, of which Simeon was but one, for its ability to link the structural concerns emphasized in political economy to the micro level behaviour of agents engaged in policy making (Campbell et al., 1960; Hofferbert, 1974).

This article demonstrates that, while the funnel of causality itself has for the most part receded from view (but see Drekker, 2014; Eger and

Matt Wilder, Department of Political Science, University of Toronto, 100 St. George, Toronto ON, M5S 3G3, Email: matt.wilder@mail.utoronto.ca

Canadian Journal of Political Science/Revue canadienne de science politique 49:4 (December/décembre 2016) 721-741 doi:10.1017/S0008423916001153 (C) 2017 Canadian Political Science Association (l'Association canadienne de science politique) and/et la Société québécoise de science politique 
Marlowe, 2006; Gunther et al., 2016), the logic of the funnel metaphor has been sustained in many neo-institutionalist approaches to the study of public policy (Weible, 2014: 398). In particular, a similar appreciation of how multi-level and multi-variable recursivity and interaction effects impact policy making can be found in subsequent work that is attentive to the institutional and sociological setting in which policy making takes place. These are generally "policy process" perspectives that take the locus of decision making as their unit of analysis, namely policy subsystems, policy communities or networks, and policy regimes (Nowlin, 2011; Schlager and Weible, 2013). ${ }^{1}$

The story is, however, nuanced. Given that the rise of neo-institutionalist approaches to the study of public policy coincided with the departure of policy studies from political economy - which fractured around the same time into critical, rational choice and neo-institutionalist variants of political economy - comprehensiveness of the sort captured by the funnel of causality was only marginally maintained in earlier work on policy subsystems, networks, communities and regimes. But as students of public policy and political economy began to reconcile their perspectives at the turn of the millennium, the sorts of multi-level relationships germane to the funnel of causality came to be increasingly emphasized in both of these literatures. Consequently, some of the most recent lines of methodological and theoretical inquiry share many affinities with the funnel of causality.

\section{The Funnel of Causality}

According to Simeon, the problem with policy studies in the 1970s - aside from a misplaced sense of purpose and an inclination toward single case analysis - was a lack of conceptual understanding. Policy scholars needed to know what variables were relevant and how they related to one another. Against the parsimony of public choice theory-in which elegant models are derived from assumptions about individuals' motivations-Simeon argued that an adequate understanding of public policy required that researchers embrace the complexity and dynamism of what he called the "process approach" (1976: 579). It is during the process of policy making that inputs interact to produce policy outputs and affect policy outcomes.

The political machinery and the policy makers at any point in time work within a framework which greatly restricts the alternatives they consider and the range of innovations they make... The framework is made up of various characteristics of the broad social and economic environment, the system of power and influence, the dominant ideas and values in the 
Abstract. If Richard Simeon's "Studying Public Policy" sought to inspire a theory of policy making, however tentative or crude, its conceptual cornerstone was no doubt the "funnel of causality." Yet references to the funnel of causality have all but disappeared from the policy literature. This article traces the evolution of the thinking that underlies the funnel of causality with the aim of demonstrating its lasting relevance to policy studies. Being a method for understanding how inputs from various levels of abstraction impact policy outcomes, the interaction and feedback effects implicit in the funnel metaphor have been maintained in subsequent neo-institutionalist work that takes seriously the institutional and sociological environment in which policy making takes place, particularly that which is interested in the origins and operation of policy subsystems, policy communities or networks, and policy regimes.

Résumé. Si l'étude "Studying Public Policy" de Richard Simeon visait à inspirer une théorie de l'élaboration des politiques, quoique provisoire ou grossière, l'entonnoir de causalité (« the funnel of causality model ») était sans doute son fondement conceptuel. Pourtant toutes les références à l'entonnoir de causalité ont disparu de la littérature politique. Cet article retrace l'évolution de la pensée sous-jacente au modèle de l'entonnoir de causalité dans le but de démontrer sa pertinence constante pour les études sur les politiques. Constituant une méthode permettant de comprendre comment les commentaires à plusieurs niveaux d'abstraction ont une incidence sur l'issue des politiques, l'interaction et les effets de rétroaction implicites dans la métaphore de l'entonnoir se sont maintenus dans les travaux néo-institutionnalistes subséquents qui accordent à l'environnement institutionnel et sociologique dans lequel s'inscrit l'élaboration des politiques sa pleine valeur, notamment celle qui s'intéresse aux origines et à l'exploitation des sous-systèmes politiques, des collectivités/réseaux et des régimes de politiques.

society, the formal institutional structures. The policy process itself... reflects and is shaped by this broader framework, and by the pattern of problems, precedents, and policies received from the past.... This perspective suggests a sort of funnel of causality. At the most general level, and most remote from the particular choice of alternative A or B, is the socioeconomic environment; next come the fundamental political variables, power, culture and ideology, and institutions; finally the most proximate source of decision is the operation of the decision-making process itself. (Simeon, 1976: 555-56)

Put differently, Simeon advocated an approach that took seriously the institutional linkages and other relationships between state, society and environment (1996). He did not argue that such an approach constituted a theory but was rather a necessary step toward theory building. The funnel of causality is theoretically tentative in that it implies inputs from different levels of abstraction coalesce to impact the scope, means and distributive effects of public policies. These inputs have causal effects by virtue of the constraints and opportunities they create for the realization of interests and ideas which are themselves shaped by the broader environmental and institutional context in which policy making takes place. 
The funnel of causality was not originally developed to explain policy decisions. Rather, it was first employed by Michigan School researchers interested in explaining voting behaviour in American elections (Campbell et al., 1960). The intention was to offer an orderly account of how temporally dispersed phenomena culminate in "psychological factors" that influence decisions. Simply put, the funnel of causality was intended to capture the "causes of causes" (Miller and Shanks, 1996).

Regardless of how the funnel of causality has been employed and for what reasons, researchers have been quite consistent in its application. Owing to the fact that it underscores relationships among input variables, the funnel of causality has acted as a guide in the selection and articulation of methodological tools, such as factor analysis (Eger and Marlowe, 2006; Hofferbert, 1974), stepwise regression (Mazmanian and Sabatier, 1980), path analysis (Hofferbert and Urice, 1985), and bloc recursive modelling (Miller and Shanks, 1996).

Insofar as policy studies are concerned, the funnel of causality came out of a large-N systems-analytic tradition referred to as DSH after its main proponents, Thomas Dye, Ira Sharkansky, and Richard Hofferbert (Blomquist, 2007). However, interest in large-N comparative work was never a prerequisite to using the funnel approach in policy research (see, for example, Mazmanian and Sabatier, 1980). Indeed, the notion that input variables converge to produce outcomes can be traced back to early systems-theoretical approaches wherein environmental characteristics create pressures for, and constraints on, political action (Easton, 1953). Still, the most forceful articulation of this concept, and that which seems to have most influenced Simeon, was Hofferbert's The Study of Public Policy (1974).

Figure 1 reproduces the funnel of causality framework put forth by Hofferbert (1974). The battery of independent variables considered by Hofferbert range from macro-structural factors at the wide end of the funnel to the micro-behaviour of elite decision makers at the narrow end. These variables exist in multi-directional relationships as evidenced by the dizzying array of arrows representing direct effects, developmental sequences, and "policy relevant incidents."

Though seemingly complex, the logic is rather simple. The last segment of the funnel - segment (e) - represents elite behaviour. As with Simeon (1976: 576), elite behaviour is a segment through which "all possible preconversion routes pass." Given that the perspective implies elite decision makers synthesize, through learning and interpretation, policy inputs into policy outcomes, theorists working from the funnel perspective made an early nod to interpretivist political science (Finlayson et al., 2004). Campbell, Converse, Miller and Stokes (1960: 29), for example, argued that "as soon as a condition is made personal, then determination of its political or non-political status can rest upon the individual's particular 
FIGURE 1

Hofferbert's Funnel of Causality

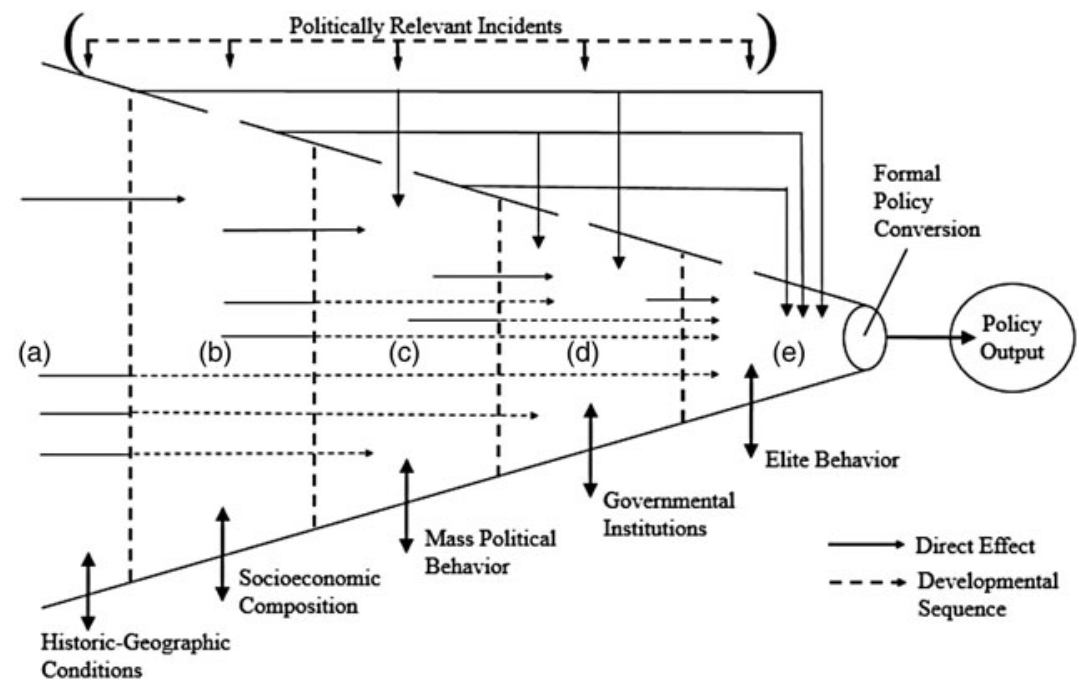

Source: Adapted from Hofferbert (1974: 228).

perceptions... we shall treat this distinction here as it occurs phenomenologically" (see also MacKuen et al., 1989). Similarly, Simeon (1976: $565)$ held that it was policy actors' perceptions that really mattered: "Given the complexity of measuring the tangible benefits and costs... the perception of benefits and costs remains vital, since it is the basis of action." Assigning preferences to elites is no good because it ignores the possibility that the pursuit of interests is constrained (Dowding et al., 1995). Understanding the influence of such constraints on decision making demands that we account for where the constraint lies on the contextual and temporal plane prior to the decision point.

Given that the logic of the funnel of causality is relatively straightforward, intuitive and complementary with long-standing statistical techniques, it may be surprising to some that it fell out of currency. While earlier research that employed the funnel of causality was critiqued for its failure to develop a theory of institutions and elite behaviour, ${ }^{2}$ it is also the case that empirical political science has since fragmented into areas of specialization - namely comparative politics, political economy, and public policy - wherein each segment of the funnel tends to be treated as the purview of a given subdiscipline to the relative exclusion of others. For instance, as noted by Simeon (1996), neo-institutionalist policy research in the early 1990s all but ignored historical-geographic conditions and socioeconomic composition, leaving the study of these phenomena to 
researchers in the field of comparative political economy (for example, Steinmo et al., 1992). The further fragmentation of neo-institutionalism into several specific varieties only moved the study of public policy farther away from comprehensive accounts of the sort the funnel intended to elucidate (Hall and Taylor, 1996; Peters, 2016; Pontusson, 1995).

\section{Whither the Funnel of Causality?}

In elections research, the funnel of causality has both reappeared and recently spawned new conceptual and methodological outgrowths (Drekker, 2014; Gunther et al., 2016). While explicit reference to the funnel of causality has waned in policy research, explicit application of methods related to it has not (see, for example, Schmidt, 1996). Rather than focus on these methods, I will focus instead on tacit engagement with the funnel's logic in the theoretical and conceptual policy literature.

Although institutionalists have always taken context seriously, the fragmentation of policy studies into various strands of neo-institutionalism has meant that debates remain over the relative influence of structure and agency, the likes of which the funnel of causality, it was hoped, would resolve (on these debates, see Hay and Wincott, 1998; Taylor and Hall, 1998). Those seeking a solution to these quandaries have emphasized a range of phenomenological (and, in some cases, hermeneutic) concepts, most notably "constitutive effects" (Snyder and Mahoney, 1999), "embeddedness" (Granovetter, 1985), and "dialectics" (Giddens, 1984; Marsh and Smith, 2000). These concepts are intended to capture that input variables interact or coalesce in the production of outputs, that relationships between structures and agents are recursive (that is, multi-directional) and that sequences are iterative in the sense that outputs at one point become inputs at another (Hay, 1998; see also Ostrom, 1990). Though not all depicted graphically in Figure 1, and despite some misunderstanding as to whether the funnel of causality takes multi-directionality and recursivity seriously (Mahoney and Snyder, 1999), all three features are prominent in the funnel of causality (Campbell et al., 1960: 25; Hofferbert, 1974: 227, 234; see also Hofferbert, 1990: 146).

While not all neo-institutionalists find it necessary to appeal to lofty concepts like constitutive effects, embeddedness or dialectics, there is a theoretical core to neo-institutionalist thinking that shares affinities with the funnel of causality (see, for example, Immergut, 1998). It is not the case that neo-institutionalists disagree on whether any confluence of input variables occurs. Rather, disagreement surrounds how much depth and analytical intricacy are needed to give an adequate account of how such confluence occurs and with what effect. Nobody doubts that the world in which policy making occurs is complex (Dowding, 2001). But policy 
making is structured to greater and lesser degrees by the setting in which it takes place, a consideration to which I will return shortly. First, it is prudent to clarify what is meant by neo-institutionalism.

\section{Neo-institutionalism}

The divorce of policy studies from political economy followed from the realization that neither the structural (macro-level) "cultural" perspective nor the individual-centred (micro-level) "calculus" approach adequately explained policy outcomes (Hall and Taylor, 1996; Pal, 1989). That is, regardless of whether political economy was approached from a structuralist (Marxian) or rationalist (public choice) perspective, the problem was the same: the analytical lens through which researchers studied politics was too abstract to capture empirical reality (Albo and Jenson, 1989). Against the former perspective, and in accord with Simeon's belief that imposing preferences on agents could only get us so far, patterns of social and economic development were beginning to be seen, at least in part, as aggregate effects of individual policy decisions, not the other way around (Atkinson, 1993; Simeon 1976: 565, 577). Yet, contrary to the strictures of conventional rational choice theory, the neo-institutionalist angle from which the majority of policy studies came to be conducted held fast to the idea that context matters (Coleman and Skogstad, 1990). ${ }^{3}$

The difference between the "old" institutionalism and neo-institutionalism lies in how institutions are defined. Whereas old institutionalism tended to consider institutions to be codified structures - such as constitutions, legislative procedures and division of powers - neo-institutionalism adopts a broader definition of institutions that includes virtually any rule or norm, including those unwritten (March and Olsen, 1989). Although neo-institutionalists disagree on the degree and extent to which context matters (Hall and Taylor, 1996), they share a sentiment that institutions constrain and condition the behaviour of agents at the micro level (Peters, 2016).

While it is arguable that every variant of neo-institutionalism is amenable to the logic of the funnel of causality, Immergut (1998) contended that historical institutionalism - a particular subset of neo-institutionalism popular among a new wave of institutionalist comparative political economists - was pathbreaking in putting forward the notion that groups internalize their collective experience (see, for example, Steinmo et al., 1992). More specifically, according to "Weberian historicism," self-reflective actors interpret their interests according to organizational and institutional logics which are themselves embedded in larger cultural contexts and traditions (Granovetter, 1985). Incoming information is not treated objectively but is rather processed (Snyder and Mahoney, 1999). From this new, interpretivist position, the funnel of causality takes on the form of "cognitive 
filters" which, though unique for each individual, are reasonably uniform among actors from similar cultural and institutional backgrounds (Denzau and North, 1994).

Considering their phenomenological slant, it should be clear by this point that proponents of the funnel of causality both anticipated and in some ways influenced subsequent developments in political science. Given that Simeon was a student of political economy (Simeon and Robinson, 1990), it is no coincidence that his perspective shared affinities with later work in the historical institutionalist vein. Consistent with Simeon's recommendations, comparative political economy underwent a shift in the late 1980s, away from deterministic explanation that relied on abstractions toward empirically driven approaches focused on observed group behaviour, constrained as it was by institutional legacies deeply rooted in national histories (Esping-Andersen, 1990). From the latter perspective, the questions pertinent to political economy are explored by studying the aggregate "partial effects" of public policies (what Mahoney, 2008, calls a "unified" approach to understanding causality). Still, policy studies and political economy were, and continue to be, distinct with respect to what is treated as the explanandum and what is treated as the explanans. For its part, neo-institutionalist political economy tends to focus on longterm patterns of institutional change, whereas policy studies continue to focus on policy outputs and outcomes. ${ }^{4}$

That said, attention to process and feedback effects on the part of policy scholars makes the overlap between the two fields unmistakable (Pierson, 1993). What earlier variants of neo-institutionalism lacked were concepts capable of capturing this overlap (Mahoney, 2008). If we imagine a continuum with structure-oriented explanation at one end and agency-focused explanation at the other, historical institutionalism and sociological/normative institutionalism continue to be primarily based on structural explanation whereas rational choice institutionalism leans further toward agency (but see Hay and Wincott, 1998, for a critique of this representation). Little is resolved by simply stating that institutions matter (Pontusson, 1995). It was against this backdrop - and against the agentless backdrop of historical institutionalism, in particular - that Vivien Schmidt advanced discursive institutionalism as the "fourth new institutionalism" (2010). ${ }^{5}$

Taking the phenomenological and interpretivist stand of "historicists" to its logical conclusion, Schmidt (2008) argued that inputs both become active and coalesce in the practice of political discourse. By analyzing discourse, we may glean how (and how much) structure matters as well as get a sense of how reflexive actors navigate structures in pursuit of their interests, sometimes changing either or both interests and institutions in the process. The parallels between the funnel of causality and discursive institutionalism are clearly evident; from both perspectives, multiple inputs from various levels of abstraction combine to guide policy behaviour at decision points. 
However, despite the precision gained by engaging with interpretivist political science, little was accomplished with respect to diminishing the complexity involved in this kind of research (Dowding, 2001). Discursive institutionalism, after all, is an approach, not a theory (Schmidt, 2010). In order to grasp how the discourse plays out in a given context, we need to take into account both the sociological setting and the institutional arrangements governing the policy process (Jones et al., 2014). Indeed, one problem identified by critics of the funnel of causality was that the policy making setting at the narrow end of the funnel was undertheorized in DSH-style research (Blomquist, 2007). Policy making does not begin and end in legislatures, after all. Subsequent research was therefore dedicated to developing an understanding of the institutional setting in which the inputs from the wide end of the funnel converge to produce policy outputs. Mazmanian and Sabatier (1980), for example, refined Hofferbert's model by better specifying the multi-level nature of the institutional environment in which policy making takes place. More recently, theories of the policy process have developed far more sophisticated accounts of how the variables at the narrow end of the funnel coalesce than did previous research in the DSH vein (Weible, 2014). While contemporary theories of the policy process are no doubt varied, the three most common concepts employed by scholars to convey the day-to-day policy making environment are policy subsystems, policy networks and policy regimes (Cairney and Heikkila, 2014; Nowlin, 2011).

Although by the mid-nineties, Simeon questioned whether neo-institutionalism was really anything new, he argued that the new institutionalist policy literature had moved "quite far along" in establishing the relationships between "macro and micro explanations," while at the same time insisting that "there is a lot more to be done in theorizing the statesociety linkage" (1996: 376,378$)$. The work to which Simeon was referring fell predominately within the policy communities and policy networks tradition, which had emerged in the late 1970s (alongside an increased focus on interest groups and non-state policy actors and organizations) as an accompaniment to the established concept of policy subsystems (Freeman, 1955; Heclo, 1978). Incidentally, the literature on policy communities and networks appeared in tandem with the advent of regime theory in international relations (Haas, 1975). Discursive institutionalism had not yet been developed at the time of Simeon's 1996 reflection; its ascent has coincided with renewed interest in policy regimes in comparative political economy (Campbell and Pedersen, 2011; Streeck and Thelen, 2005).

The subsections to follow summarize how the literature on policy subsystems, policy communities or networks and policy regimes has incorporated the dynamism of the funnel of causality. My aim is to demonstrate that, while the logic of the funnel of causality was never abandoned entirely, 
it has become more pronounced in recent years as policy scholars have embraced interpretivism, on one hand, and multi-level understandings of the settings in which policy making takes place, on the other (Schlager and Weible, 2013: 392).

Policy subsystems, communities, networks and regimes are slippery concepts (Orr, 2006). Depending on how precisely one defines these terms, these concepts may be viewed as competing interpretations of the setting in which policy making takes place, as complementary "nested" concepts, or as virtually synonymous (Cairney and Heikkila, 2014). We have not seen one of these terms replacing another over time; rather, they have become increasingly referenced in the literature, with the popularity of each concept growing in near perfect unison with the others.

In their original formulation, policy subsystems were considered to be physically "closed" - that is, administratively isolated from the larger political system - and thus distinct from policy communities and policy networks, the latter two of which were understood to be concerned with a single policy area but capable of spanning several subsystems (Freeman, 1955; Heclo, 1978). Policy regimes have always been understood in broader terms, encompassing multiple subsystems, sometimes multiple policy sectors, and often traversing national borders (Eisner, 1993). While globalization and contemporary governance have drawn these concepts closer to one another (to the point that policy networks and policy subsystems are often used interchangeably; see Cairney and Heikkila, 2014: $365)$, policy regimes are unique in that both membership and compliance tend to be voluntary, relying to a greater extent on shared norms than formal rules (Haas, 1989). ${ }^{6}$

\section{Policy subsystems}

The concept of policy subsystems has been around for some time. Defined as relatively closed and autonomous policy making forums, policy subsystems were explained by Freeman (1955) as resulting from idiosyncrasies of the American political system, notably the receptivity of executive bureaus and legislative committees to organized interests (see, for example, Lindblom, 1968). It is no coincidence, then, that the American policy literature has made great use of subsystems as a conceptual tool. In particular, influential works in the punctuated equilibrium and advocacy coalition schools have been responsible for the popularization of the subsystems concept beyond the American context to which it most closely applied (Baumgartner and Jones, 1993; Sabatier and Jenkins-Smith, 1993).

Similar to the concept of "iron triangles" that preceded it, policy subsystems were conventionally theorized to be status-quo oriented, producing predictable, incremental policy outputs. Regarding the segments in the funnel of causality, institutions governing subsystems were assumed to 
be deterministic in that they promote a "structure-induced equilibrium," which prevents internal mobilizations of bias while limiting access to the subsystem to a fairly narrow set of organized interests (Shepsle, 1979). While socioeconomic factors were acknowledged to produce a plurality of biases within the larger polity, these signals were considered to be largely inconsequential to the isolated operations of policy subsystems. From this perspective, only when tremendous institutional inertia is overcome is the incremental pattern of subsystemic policy making broken, resulting in a policy punctuation that often coincides with the destruction or restructuring of affected subsystems (Jones and Baumgartner, 2005).

Although the closedness implied by the conventional definition of policy subsystems privileged exogenous pressures for policy change over learning among participants internal to the subsystem, more recent scholarship has relaxed assumptions about the degree to which subsystemic policy making takes place behind closed doors (Howlett and Ramesh, 1998). Since its inception, the advocacy coalition framework, for instance, has defined the policy subsystem as encompassing a wider variety of actors than just those associated with government operations (such as academics and media representatives) (Sabatier and Jenkins-Smith, 1993). Whereas punctuated equilibrium theory held closely to the classical definition of policy subsystems in its initial formulation, it too has incorporated a sophisticated theory of information processing that explains endogenous policy change as a product of "reframing" among participants internal to the subsystem (Eissler et al., 2016).

While it has been pointed out that subsystems are considered to be more open in the advocacy coalition literature than they are from the punctuated equilibrium perspective, all of the mainstream theories of the policy process recognize that contemporary governance is defined by much more fluid flows of information, if not personnel, than was typically the case in the past (Cairney and Heikkila, 2014: 382-83). Consequently, complexity has been gradually reintroduced to policy theory as evidenced by recent preoccupation with transboundary policy dynamics, discourse, narratives, and culture (Jenkins-Smith et al., 2014; Leifeld, 2013; Schlager and Weible, 2013). To be clear, important differences no doubt exist with respect to how policy is made from one jurisdiction to another. It is no longer sufficient, however, to view such differences as country specific (see, for example, Knoke et al., 1996). The origins of the policy communities and policy networks literature are illustrative in this regard.

\section{Policy communities and policy networks}

Critiquing the closedness of the "disastrously incomplete" subsystem perspective, Heclo (1978: 88) argued that "looking for the closed triangles of control, we tend to miss the fairly open networks of people that 
increasingly impinge upon government." Where subsystems were understood to make complex policy issues simple by winnowing the issues they handle to a tractable number of dimensions (Baumgartner and Jones, 1993: 16), policy communities and networks were said to seek out complexity in what might seem at first to be simple issues (Heclo, 1978: 119). Regardless of the specific terminology, the crucial variable is the relative openness of the policy-making process (Howlett and Ramesh, 1998). Put differently, the difference between policy subsystems and policy communities and networks boiled down to differences of institutional configurationsuch as decision rules and the arrangement of veto points - and the level of policy stability that followed therefrom (Peters, 2016: 63).

While more recent theorizing on policy communities and networks has tended to see policy making as quite open and consultative, earlier work saw the policy making process as still quite closed but nevertheless contested (Atkinson and Coleman, 1989; Knoke et al., 1996; Pross, 1986). As Skogstad (2008) points out, theorizing on policy communities and networks originated at about the same time on both sides of the Atlantic, but unfortunately for what was a predominantly Canadian school, the British approach to studying policy communities and networks had a much more lasting impact (Marsh and Rhodes, 1992).

Consequently, the British approach to studying policy communities and networks gave rise to a second wave of community and network scholarship in the late 1990s that emphasized strategic action on the part of reflexive agents and their ability to work "discursively" within constraints to realize their ends (Hay, 1998; Marsh, 1998). Simultaneously less structuralist and more constructivist - and therefore less predictable - than the image conveyed by either the subsystems literature or earlier musings on policy communities and networks, this new wave of discourse-oriented community and network studies invoked a "dialectical" approach to studying public policy that emphasized multi-iterative and recursive relationships between variables nested at different levels of abstraction. ${ }^{7}$

How does the literature on policy communities and networks accord with the project laid out in "Studying Public Policy"? On the first wave of community and network studies, Simeon had this to say: "while not wanting to denigrate the institutionalists, I do want to stress that it is essential to keep our eye on the context, the environment, the social, economic, and attitudinal settings in which governing structures and policy networks are embedded, and to underline the need to trace the linkages between them" (1996: 381). In this sense, the first wave of policy community and policy network studies, although on the right track, did not, according to Simeon, account sufficiently for macro phenomena and their impact on attitudes and ideas. In a manner of speaking, these studies employed a short funnel perspective, wherein the spatial organization of policy actors and the institutions governing them determine the strategies pursued by 
policy actors (Dowding, 1995). More so than the first wave of community and network studies, the second wave of community and network studies emphasized a phenomenological or interpretivist orientation that was in many ways similar to the funnel approach.

As mentioned above, few current works make concrete distinctions between policy communities, policy networks and policy subsystems. To emphasize a previous point, the disappearance of such distinctions follows in part from the recognition that even physically isolated policy making forums are open to a range of informational inputs (Baumgartner and Jones, 2015). Recent interest in the politics of information has led researchers to shift their focus away from a strictly physical interpretation of policy access toward informational access and the corresponding politics of cognition and deliberation (Jones et al., 2014). This interpretive turn has effectively bridged old divides between subsystem-focused research and that which invoked policy communities and networks as alternative concepts.

I do not wish to give the impression that policy researchers have become ambivalent about structural variables. On the contrary, old distinctions between subsystems and networks were abandoned because the variety of observed institutional configurations created doubts about how incisive such a dichotomy really was (Howlett and Ramesh, 1998). As it happens, recent theoretical innovations devised to account for the wide range of policy influences have corresponded with the rediscovery of regimes as a useful device for comprehending how policy making is structured.

\section{Policy regimes}

Not only does regime theory have advocates on both sides of divide separating political economy from policy studies (Streeck and Thelen, 2005), it also marries many of the insights gained from the subsystems and networks literatures (Jochim and May, 2010; Orr, 2006). Policy regimes are large and somewhat amorphous, like communities or networks, but are also structured, like subsystems. Unlike the conventional image of subsystems, however, policy regimes do not rely solely on formal institutions for their structure; rather, they rely in large part on informal and highly flexible institutions that emerge as a consequence of shared ideas and interests - which are considered to be inseparable - about policy ends and the appropriate means for achieving them (Scharpf, 1997: 141-42).

Whereas analytical frameworks (like the funnel of causality) lay out the relevant variables and the relationships between them, theories privilege some variables over others. ${ }^{8}$ Owing to its basis in elite theory, work on policy regimes tends to favour influence, that is, a "power to" (as opposed to a "power over") conception of power (Stone, 1993). More specifically, 
regime theory tells a story about how and why influential groups come to dominate the policy agenda by elevating their interpretation of possible policy directions over other alternatives (Campbell and Pedersen, 2011).

The literature on policy regimes is theoretical-and not simply descriptive - in that it encompasses a microfoundational theory of collective action (Worsham, 2013; also Ostrom, 1990: ch. 2, 6). Beyond playing the role of broker, in the course of setting up and maintaining policy regimes, the state is theorized to absorb co-ordination costs assumed to be prohibitive in the eyes of private actors (Haas, 1989; Young, 1980). Individual or organizational interests beyond those that can be realized unilaterally are satisfied by "coupling" them to government goals, which often require private resources (financial and/or technical) or the sanction of certain "advantaged" groups to be achieved (Dowding et al., 1995; Jones and Bachelor, 1993; Stone, 1989). In order to legitimize the political commitment to regime creation and maintenance, the state must rally broad support, precipitating a bandwagoning effect whereby many different interests attempt to attach their preferred policy solutions to the agenda. Crucially, while the state has incentives to mobilize as much popular bias as possible in favour of its programmes, the trade-off in the eyes of large private organizations is more precarious; if compromises are such that lead (private) organizations perceive unilateral action as a more efficient means of achieving their interests, they will withdraw from the regime, imperiling it in the process (Olson, 1971).

How does regime theory correspond to the funnel of causality? Providing a clearer picture of structural and agential variables than was typical of earlier work in the DSH vein, regime theory intends to capture the dynamics that lead to policy innovation in particular institutional environments (Eisner, 1993). Drawing on the tacit post-positivism of Riker's work (1996) on rhetoric and persuasion, "policy entrepreneurs" are hypothesized to process signals from the environment, combining various policy alternatives in novel ways as they exploit institutional connections to set up and co-ordinate regimes. Dropping the neo-classical conception of homo economicus in favour of Mises's (1966) reflexive homo agens, such experiments with policy innovation and "policy arbitrage" mobilize biases that set policy bandwagons in motion (Schneider et al., 1995; Worsham, 2013). It is in this sense that regime theory is at once formal, interpretivist, and complementary with discursive institutionalism (notwithstanding some unease regarding incompatible ontologies; see, for example, Jones and Radaelli, 2015).

The ingenuity involved in, first, translating signals into problem definitions and, second, attaching them to acceptable solutions is articulated in the policy discourse. Discourse gels the levels of abstraction denoted by the five segments in the funnel of causality. Given the fact of pluralism, regime theory anticipates that acceptable policy solutions are most often, in actuality, bundles of solutions combined throughout the deliberative process 
(Stone, 1993). What discursive institutionalism brings to this discussion is a perspective that is unapologetic in its insistence that interests are formed and mediated by discourse.

Methodologically, discourse analysis provides a means for understanding how signal processing, policy innovation and arbitrage, and the mobilization of policy bandwagons play out. It should be stressed, however, that discourse analysis is by no means a tool suited exclusively to regime theory (see Leifeld, 2013, for an analysis of "discourse networks" using the advocacy coalition framework, for example). Discourse, facilitated as it is by entrepreneurs and structured as it is by institutions, gives organized interests and the apathetic coherent stories upon which to base their preferences. Successful rhetors get people to see things in a new light or realize that their interests will be served by a given proposal (Riker, 1996). It would of course be naïve to assume that all actors are similarly impelled by the dominant discourse. Some actors will be persuaded while others resist or resign to "going along" (Elkin, 1987). In regime-theoretic terms, an appreciation of the relative influence of the actors involved allows for the dynamics of regime creation, maintenance and dissolution to be formally modelled (Dowding et al., 1995). Consequently, regime theory is more positivist in tone than the second wave of policy network studies, yet regime theory is nevertheless interpretivist in substance.

\section{Conclusion}

Although the funnel of causality is no longer part of policy scholars' toolbox, its underlying logic - that inputs from different levels of abstraction affect policy outcomes - remains foundational to contemporary neo-institutionalist approaches to studying public policy. The evolution of the field has not been straightforward, however. Two aspects of Simeon's project, in particular, did not receive adequate attention in earlier research, including that which evoked the funnel metaphor. First, in spite of the fact that advocates of the funnel of causality placed great emphasis on the locus of decision making, the actual process of policy making was not given due consideration in the large-N comparative studies of Dye, Sharkansky and Hofferbert (Blomquist, 2007). Second, owing to "difficulties of measurement" and a "poverty of appropriate theory," the phenomenological and interpretivist orientation of its architects was not sustained in much of the research that made use of the funnel of causality (Hofferbert, 1990: 146-47).

The appearance of policy process theories overcame the supposed limitations of the funnel of causality by specifying the physical setting in which policy is made as the appropriate unit of analysis (Sabatier, 2007; Weible, 2014). However, regardless of whether these approaches invoked policy subsystems, networks, communities or regimes, many failed in their 
original formulations to capture the sociological and socio-structural context of policy making (Simeon, 1996). Although the notion of "embedded autonomy" has been around for some time (see Granovetter, 1985), it was not until the advent of neo-institutionalism - and discursive institutionalism, in particular - that the interpretivist inclination of early proponents of the funnel of causality returned full force to the main stream of policy studies (see, for example, Eissler et al., 2016; Jones et al., 2014).

The many themes the funnel of causality sought to incorporate into the study of public policy have thus come to be increasingly pronounced in the literature. This reconciliation of different perspectives on public policy has involved something of a rapprochement between neo-institutionalist policy studies and neo-institutionalist political economy by way of a common interest in the mediative power of discourse (Schmidt, 2010). By adopting a stance that considers large scale social and economic trends to be a consequence of "partial effects" of individual policies at the case level (as per Mahoney's "unified theory of causality," 2008), the lines delineating policy studies from political economy have become blurred once more as both fields have come to embrace causal dynamism, interpretivism and, most recently, a common understanding of how regimes are created and change (Campbell and Pedersen, 2011; Streeck and Thelen, 2005).

While it is clear that researchers no longer find it necessary to make explicit reference to the funnel of causality, it continues to be a helpful conceptual heuristic for sorting out the origins of input variables in policy research (Mazmanian and Sabatier, 1980: 464). The advent of interpretive political science, although a welcome advancement on the kind of thinking the funnel of causality intended but ultimately failed to encourage, has not made policy research any more orderly. Just as the funnel of causality is not itself a theory of politics, neither is interpretivism.

Questions related to how agents gather, interpret and ultimately use information are, however, central to theories of policy making (Jones, 1994). Seen in this light, the funnel of causality remains useful for parsing the relative influence of environment, power, ideas, institutions, and process (Eger and Marlowe, 2006). With respect to how these inputs interact, empirical analysis provides opportunities to explore what combinations of factors constitute necessary and sufficient conditions in the production of policy outputs and outcomes. As Simeon argued forty years ago, only by repeating analysis of this sort across a variety of policy settings and policy sectors might we hope to develop a general theory of policy making.

\section{Endnotes}

1 As has been pointed out by Sabatier (2007) and Weible (2014), the logic of the funnel of causality has been subsumed, to greater and lesser degrees, by several of the most popular theories of the policy process, particularly the advocacy coalition framework 
(Sabatier and Jenkins-Smith, 1993) and institutional analysis and development (Ostrom, 1990).

2 Commenting on ambiguities surrounding the causal mechanism in Hofferbert's framework, Schlager points out that elite behaviour was underdeveloped in DSH research (Schlager, 2007: 313). Blomquist argues that insofar as the funnel of causality implies both a unitary policy environment and a unitary decision maker, it fails to account for the plurality of institutions and decision points emblematic of contemporary public policy (Blomquist, 2007: 272; see also Hofferbert, 1990). Eger and Marlowe insist, however, that these criticisms are easily rebuffed, contending that the funnel of causality "may be far more parsimonious than many of the models currently considered within the literature" (2006: 426).

3 Hence the emergence of "meso-level analysis" and its popularity among policy scholars (Jones et al, 2014; Marsh and Rhodes, 1992).

4 This is admittedly somewhat of a simplification. Skogstad (2005), while no doubt interested in "who gets what," accounts for distributive outcomes by explaining institutional changes that precede them. Inversely, Esping-Andersen (1990) is able to account for the origins of political and economic institutions only by first explaining political representation and the benefits accrued therefrom. In Simeon's view, political economy and public policy could not be properly studied on their own; explaining outcomes at "one end of the funnel" required an understanding of what was going on at the other end (1976: 556).

5 Perhaps to the chagrin of proponents of "constructivist" or "interpretivist institutionalism" (Hay, 2011), Schmidt seems to have been successful in collapsing any approach that "takes discourse seriously" into discursive institutionalism as a general perspective (Schmidt, 2008; 2010).

6 As Clarence Stone put it, "what makes it more than an 'ecology of games'? The answer is that the regime is purposive, created and maintained as a way of facilitating action. In a very important sense, a regime is empowering" (Stone, 1989: 4, italics in original).

7 According to these scholars, dialectic denotes causal interplay: "In our usage a dialectical relationship is an interactive relationship between two variables in which each affects the other in a continuing iterative process" (Marsh and Smith, 2000: 5). Evans (2001) points out, however, that "dialectic" is a dangerous term open to misinterpretation. The standard definition of dialectic evokes an image of tense and contradictory relationships between units of analysis, such as those between agents and context (Warren, 1984).

8 My thanks to Evert Lindquist for this way of putting it.

\section{References}

Albo, Gregory and Jane Jenson. 1989. "A Contested Concept: The Relative Autonomy of the State." In The New Canadian Political Economy, ed. Wallace Clement and Glen Williams. Montreal: McGill-Queen's University Press.

Atkinson, Michael M. 1993. "Public Policy and the New Institutionalism." In Governing Canada: Institutions and Public Policy, ed. M. Atkinson. Toronto: Harcourt.

Atkinson, Michael M. and William D. Coleman. 1989. The State, Business, and Industrial Change in Canada. Toronto: University of Toronto Press.

Baumgartner, Frank R. and Bryan D. Jones. 1993. Agendas and Instability in American Politics. Chicago: University of Chicago Press.

Baumgartner, Frank R. and Bryan D. Jones. 2015. The Politics of Information. Chicago: University of Chicago Press. 
Blomquist, William. 2007. "The Policy Process and Large-N Comparative Studies." In Theories of the Policy Process, ed. Paul Sabatier. $2^{\text {nd }}$ ed. Boulder: Westview.

Cairney, Paul and Tanya Heikkila. 2014. "A Comparison of Theories of the Policy Process." In Theories of the Policy Process, ed. Paul A. Sabatier and Christopher Weible. $3^{\text {rd }}$ ed., Boulder: Westview.

Campbell, Angus, Philip E. Converse, Warren E. Miller and Donald E. Stokes. 1960. The American Voter. Chicago: University of Chicago Press.

Campbell, John L. and Ove K. Pedersen. 2011. "Knowledge Regimes and Comparative Political Economy." In Ideas and Politics in Social Science Research, ed. Daniel Béland and Robert H. Cox. Oxford: Oxford University Press.

Coleman, William D. and Grace Skogstad. 1990. "Policy Communities and Policy Networks: A Structural Approach.” In Policy Communities and Public Policy in Canada, ed. W. Coleman and G. Skogstad. Mississauga ON: Copp Clark Pitman.

Denzau, Arthur T. and Douglass C. North. 1994. "Shared Mental Models: Ideologies and Institutions." Kyklos 47 (1): 3-31.

Dowding, Keith. 1995. "Model or Metaphor? A Critical Review of the Policy Network Approach." Political Studies 43 (1): 137-58.

Dowding, Keith. 2001. "There Must Be End to Confusion: Policy Networks, Intellectual Fatigue, and the Need for Political Science Methods Courses in British Universities." Political Studies 49 (1): 89-105.

Dowding, Keith, Patrick Dunleavy, Desmond King and Helen Margetts. 1995. "Rational Choice and Community Power Structures." Political Studies 43 (2): 265-77.

Drekker, Henk. 2014. "Voting and Not Voting: The Principal Explanations." In The Palgrave Handbook of Global Political Psychology, ed. Paul Nesbitt-Larking, Catarina Kinnvall and Tereza Capelos. London: Palgrave.

Easton, David. 1953. A Systems Analysis of Political Life. New York: Alfred Knopf Co.

Eger, Robert J. and Justin Marlowe. 2006. "Hofferbert in Transit: A Dynamic Stages Model of the Urban Policy Process." Review of Policy Research 23 (2): 413-32.

Eisner, Marc A. 1993. Regulatory Politics in Transition. Baltimore: Johns Hopkins University Press.

Eissler, Rebecca, Annelise Russell and Bryan D. Jones. 2016. "The Transformation of Ideas: The Origin and Evolution of Punctuated Equilibrium Theory." In Contemporary Approaches to Public Policy, ed. B. Guy Peters and Philippe Zittoun. London: Palgrave Macmillan.

Elkin, Stephen L. 1987. City and Regime in the American Republic. Chicago: University of Chicago Press.

Esping-Andersen, Gøsta. 1990. The Three Worlds of Welfare Capitalism. Cambridge: Polity.

Evans, Mark. 2001. "Understanding Dialectics in Policy Network Analysis." Political Studies 49 (3): 542-50.

Finlayson, Alan, Mark Bevir, R. A. W. Rhodes, Keith Dowding and Colin Hay. 2004. "The Interpretive Approach in Political Science." The British Journal of Politics and International Relations 6 (2): 129-64.

Freeman, John L. 1955. The Political Process. Garden City NY: Doubleday.

Giddens, Anthony. 1984. The Constitution of Society. Cambridge: Polity.

Granovetter, Mark. 1985. "Economic Action and Social Structure: The Problem of Embeddedness." American Journal of Sociology 91 (3): 481-510.

Gunther, Richard, Paul A. Beck, Pedro C. Magalhães and Alejandro Moreno, eds. 2016. Voting in Old and New Democracies. New York: Routledge.

Haas, Ernst. 1975. “On Systems and International Regimes." World Politics 27 (2): 147-74.

Haas, Peter. 1989. "Do Regimes Matter? Epistemic Communities and Mediterranean Pollution Control.” International Organization 43 (3): 377-403. 
Hall, Peter A., and Rosemary Taylor. 1996. "Political Science and the Three New Institutionalisms." Political Studies 44 (5): 936-57.

Hay, Colin. 1998. "The Tangled Webs We Weave: The Discourse, Strategy and Practice of Networking." In Comparing Policy Networks, ed, D. Marsh. Buckingham: Open University Press.

Hay, Colin. 2011. "Interpreting Interpretivism Interpreting Interpretations: The New Hermeneutics of Public Administration." Public Administration 89 (1): 167-82.

Hay, Colin and Daniel Wincott. 1998. "Structure, Agency and Historical Institutionalism." Political Studies 46 (5): 951-57.

Heclo, Hugh. 1978. "Issue Networks and the Executive Establishment." In The New Political System, ed. Anthony King. Washington: The American Enterprise Institute.

Hofferbert, Richard. 1974. The Study of Public Policy. Indianapolis: Bobbs-Merrill.

Hofferbert, Richard. 1990. The Reach and Grasp of Policy Analysis. Tuscaloosa: University of Alabama Press.

Hofferbert, Richard and John K. Urice. 1985. "Small-Scale Policy: The Federal Stimulus versus Competing Explanations for State Funding of the Arts." American Journal of Political Science 29 (2): 308-29.

Howlett, Michael and Mishra Ramesh. 1998. "Policy Subsystem Configurations and Policy Change." Policy Studies Journal 26 (3): 466-81.

Immergut, Ellen. 1998. "The Theoretical Core of the New Institutionalism." Politics and Society 26 (1): 5-34.

Jenkins-Smith, Hank, Carol L. Silva, Kuhika Gupta and Joseph T. Ripberger. 2014. "Belief System Continuity and Change in Policy Advocacy Coalitions: Using Cultural Theory to Specify Belief Systems, Coalitions, and Sources of Change." Policy Studies Journal 42 (4): 484-508.

Jochim, Ashley E. and Peter J. May. 2010. "Beyond Subsystems: Policy Regimes and Governance.” Policy Studies Journal 38 (2): 303-27.

Jones, Bryan D. 1994. Reconceiving Decision-Making in Democratic Politics. Chicago: University of Chicago Press.

Jones, Bryan D. and Frank R. Baumgartner. 2005. The Politics of Attention. Chicago: University of Chicago Press.

Jones, Bryan D. and Lynn Bachelor. 1993. The Sustaining Hand. $2^{\text {nd }}$ ed. Lawrence: University Press of Kansas.

Jones, Michael D. and Claudio M. Radaelli. 2015. "The Narrative Policy Framework: Child or Monster?" Critical Policy Studies 9 (3): 339-55.

Jones, Michael D., Mark K. McBeth and Elizabeth A. Shanahan. 2014. "Introducing the Narrative Policy Framework." In The Science of Stories, ed. Michael, Jones D., Elizabeth A. Shanahan and Mark K. McBeth. New York: Palgrave Macmillan.

Knoke, David., Franz Urban Pappi, Jeffrey Broadbent and Yutaka Tsujinaka. 1996. Comparing Policy Networks. New York: Cambridge University Press.

Leifeld, Philip. 2013. "Reconceptualizing Major Policy Change in the Advocacy Coalition Framework: A Discourse Network Analysis of German Pension Politics." Policy Studies Journal 41 (1): 169-98.

Lindblom, Charles Edward. 1968. The Policy-Making Process. Englewood Cliffs NJ: Prentice-Hall.

MacKuen, Michael B., Robert S. Erikson and James A. Stimson. 1989. "Macropartisanship." American Political Science Review 83 (4): 1125-42.

Mahoney, James. 2008. "Toward a Unified Theory of Causality." Comparative Political Studies 41 (4-5): 412-36.

Mahoney, James and Richard Snyder. 1999. "Rethinking Agency and Structure in the Study of Regime Change." Studies in Comparative International Development 34 (2): 3-32. 
March, James G., and Johan P. Olsen. 1989. Rediscovering Institutions. New York: Free Press.

Marsh, David. 1998. "The Utility and Future of Policy Network Analysis." In Comparing Policy Networks, ed. D.Marsh. Buckingham: Open University Press.

Marsh, David and Martin Smith. 2000. "Understanding Policy Networks: Towards a Dialectical Approach." Political Studies 48 (1): 4-21.

Marsh, David, and R. A. W. Rhodes, eds. 1992. Policy Networks in British Government. Clarendon: Oxford University Press.

Mazmanian, Daniel A. and Paul A. Sabatier. 1980. "A Multivariate Model of Public PolicyMaking.” American Journal of Political Science 24 (3): 439-68.

Miller, Warren E. and J. Merrill Shanks. 1996. The New American Voter. Cambridge: Harvard University Press.

Mises, Ludwig. 1966. Human Action. Chicago: H. Regnery.

Nowlin, Matthew. 2011. "Theories of the Policy Process: State of the Research and Emerging Trends." Policy Studies Journal 39 (1): 41-60.

Olson, Mancur. 1971. The Logic of Collective Action. 2nd ed. Cambridge MA: Harvard University Press.

Orr, Shannon K. 2006. "Policy Subsystems and Regimes: Organized Interests and Climate Change Policy." Policy Studies Journal 34 (2): 147-69.

Ostrom, Elinor. 1990. Governing the Commons: The Evolution of Institutions for Collective Action. Cambridge: Cambridge University Press.

Pal, Leslie A. 1989. "Political Economy as a Hegemonic Project." Canadian Journal of Political Science 22 (4): 827-40.

Peters, B. Guy. 2016. "Institutionalism and Public Policy." In Contemporary Approaches to Public Policy, ed. B. Guy Peters and Philippe Zittoun. London: Palgrave Macmillan.

Pierson, Paul. 1993. "When Effect Becomes Cause: Policy Feedback and Political Change." World Politics 45 (4): 595-628.

Pontusson, Jonas. 1995. "From Comparative Public Policy to Political Economy: Putting Political Institutions in Their Place and Taking Interests Seriously." Comparative Political Studies 28 (1): 117-47.

Pross, Paul. 1986. Group Politics and Public Policy. Toronto: Oxford University Press.

Riker, William H. 1996. The Strategy of Rhetoric. New Haven: Yale University Press.

Sabatier, Paul A. 2007. "Introduction: The Need for Better Theories." In Theories of the Policy Process, ed. P. Sabatier. 2nd ed. Boulder: Westview.

Sabatier, Paul A. and Hank Jenkins-Smith, eds. 1993. Policy Change and Learning: An Advocacy Coalition Approach. Theoretical Lenses on Public Policy. Boulder: Westview.

Scharpf, Fritz. 1997. Games Real Actors Play. Boulder: Westview.

Schmidt, Manfred G. 1996. "When Parties Matter: A Review of the Possibilities and Limits of Partisan Influence on Public Policy." European Journal of Political Research 30 (2): $155-83$.

Schmidt, Vivien A. 2008. "Discursive Institutionalism: The Explanatory Power of Ideas and Discourse." Annual Review of Political Science 11 (1): 303-26.

Schmidt, Vivien A. 2010. "Taking Ideas and Discourse Seriously: Explaining Change through Discursive Institutionalism as the Fourth 'New Institutionalism"' European Political Science Review 2 (1): 1-25.

Schneider, Mark, Paul Teske and Michael Mintrom. 1995. Public Entrepreneurs: Agents for Change in American Government. Princeton: Princeton University Press.

Schlager, Edella. 2007. "A Comparison of Frameworks, Theories, and Models of Policy Processes." In Theories of the Policy Process, ed. P. Sabatier. 2nd ed. Boulder: Westview.

Schlager, Edella, and Chris Weible. 2013. "New Theories of the Policy Process." Policy Studies Journal 41 (3): 389-96. 
Shepsle, Kenneth A. 1979. "Institutional Arrangements and Equilibrium in Multidimensional Voting Models." American Journal of Political Science 23 (1): 27-59.

Simeon, Richard. 1976. "Studying Public Policy." Canadian Journal of Political Science 9 (4): 548-80.

Simeon, Richard. 1996. "Afterword: 'New' Directions in Canadian Policy Studies." In Policy Studies in Canada: The State of the Art, ed. L. Dobuzinskis, M. Howlett and D. Laycock. Toronto: University of Toronto Press.

Simeon, Richard, and Ian Robinson. 1990. State, Society, and the Development of Canadian Federalism. Toronto: University of Toronto Press Toronto.

Skogstad, Grace. 2005. "The Dynamics of Institutional Transformation: The Case of the Canadian Wheat Board." Canadian Journal of Political Science 38 (3): 529-48.

Skogstad, Grace. 2008. "Policy Networks and Policy Communities: Conceptualizing StateSocietal Relationships in the Policy Process." In The Comparative Turn in Canadian Political Science, ed. L. White, R. Simeon, R. Vipond and J. Wallner. Vancouver: UBC Press.

Snyder, Richard and James Mahoney. 1999. "The Missing Variable: Institutions and the Study of Regime Change." Comparative Politics 32 (1): 103-22.

Steinmo, Sven, Kathleen Thelen and Frank Longstreth, eds. 1992. Structuring Politics: Historical Institutionalism in Comparative Analysis. Cambridge: Cambridge University Press.

Stone, Clarence N. 1989. Regime Politics: Governing Atlanta, 1946-1988. Lawrence: University Press of Kansas.

Stone, Clarence N. 1993. "Urban Regimes and the Capacity to Govern: A Political Economy Approach." Journal of Urban Affairs 15 (1): 1-28.

Streeck, Wölfgang and Kathleen Thelen. 2005. "Introduction: Institutional Change in Advanced Political Economies.” In Beyond Continuity, ed. W. Streeck and K. Thelen. New York: Oxford University Press.

Taylor, Rosemary and Peter A. Hall. 1998. "The Potential of Historical Institutionalism: A Response to Hay and Wincott." Political Studies 46 (5): 958-62.

Warren, Scott. 1984. The Emergence of Dialectical Theory. Chicago: University of Chicago Press.

Weible, Christopher. 2014. “Advancing Policy Process Research.” In Theories of the Policy Process, ed. Paul Sabatier and Christopher M. Weible. $3^{\text {rd }}$ ed. Boulder: Westview.

Worsham, Jeff. 2013. "Tilting at Windmills: Constructing Policy Regimes." Paper presented at the International Conference on Public Policy, Grenoble, France.

Young, Oran R. 1980. "International Regimes: Problems of Concept Formation." World Politics 32 (3): 331-56. 